\title{
MODEL-MODEL EVALUASI PENDIDIKAN
}

Oleh:

Mardiah \& Syarifuddin

Dosen STAI Auliaurrasyidin Tembilahan

\begin{abstract}
ABSTRAK
Evaluasi merupakan salah satu komponen dari sistem pendidikan Islam yang harus dilakukan secara sistematis dan terencana sebagai alat untuk mengukur keberhasilan atau target yang akan dicapai dalam proses pendidikan atau proses pembelajaran. Model-model evaluasi pendidikan adalah contoh atau pola acuan suatu proses penilaian dalam mengumpulkan dan menganalisis untuk menentukan taraf kemajuan suatu aktivitas di dalam pendidikan guna menetapkan pencapaian suatu tujuan baik untuk pendidik dan peserta didik. Adapun modelmodel evaluasi pendidikan adalah Goal Oriented Evaluation Model, Goal Free Evaluation Model, Formatif Sumatif Evaluation, dan Countenance Evaluation Model
\end{abstract}

Kata Kunci: Model, Evaluasi Pendidikan.

\section{PENDAHULUAN}

\section{A. Latar Belakang Masalah}

Dalam setiap perencanaan dan kegiatan selalu membutuhkan evaluasi ${ }^{1}$, tujuannya adalah untuk mengetahui kegagalan atau keberhasilan sebuah perencanaan atau kegiatan tersebut. Tetapi, tidak semua orang menyadari bahwa setiap kita selalu melakukan pekerjaan evaluasi. ${ }^{2}$

${ }^{1}$ Evaluasi adalah kata kunci akhir dalam melihat sebuah perencanaan. Ia menjadi tolok ukur kegagalan dan keberhasilan sebuah program/kegiatan. Oleh karena itu, evaluasi atau ukuran penilaian tidak bisa ditinggalkan. Ia mutlak dilaksanakan untuk mengetahui kelemahan dan kelebihan sebuah perencanaan. lih. Neneng Lina, Perencanaan Pendidikan, (Bandung: Pustaka Setia, 2001), h. 233

${ }^{2}$ Suharsimi Arikunto, Dasar-dasar Evaluasi Pendidikan, (Jakarta: Bumi Aksara, 2007), ed. Revisi, cet. 7, h. 1 
Ada benarnya apa yang dikatakan oleh Ramayulis bahwa evaluasi sangat dibutuhkan dalam berbagai kegiatan kehidupan manusia sehari-hari, karena disadari atau tidak, sebenarnya evaluasi sudah sering dilakukan, baik untuk diri sendiri maupun kegiatan sosial lainnya. Hal ini dapat dilihat mulai dari berpakaian, setelah berpakaian ia berdiri dihadapan kaca apakah penampilannya sudah wajar atau belum. ${ }^{3}$

Adapun pengertian evaluasi adalah pengambilan keputusan berdasarkan hasil pengukuran dan standar kriteria. ${ }^{4}$ Evaluasi juga diartikan sebagai kegiatan atau proses untuk menilai sesuatu. ${ }^{5}$ Sedangkan menurut Marrison evaluasi adalah perbuatan pertimbangan berdasarkan seperangkat kriteria yang disepakati dan dapat dipertanggungjawabkan. ${ }^{6}$

Dalam Pendidikan Islam, evaluasi merupakan salah satu komponen dari sistem pendidikan Islam yang harus dilakukan secara sistematis dan terencana sebagai alat untuk mengukur keberhasilan atau target yang akan dicapai dalam proses pendidikan atau proses pembelajaran. ${ }^{7}$

Dalam ilmu evaluasi program pendidikan, ada banyak model yang bisa digunakan untuk mengevaluasi suatu program. Meskipun antara satu dengan yang lainnya berbeda, namun maksudnya sama yaitu melakukan kegiatan pengumpulan data atau informasi yang berkenaan dengan objek yang dievaluasi, yang tujuannya menyediakan bahan bagi pengambil keputusan dalam menentukan tindak lanjut suatu program. Adapun tujuan dalam penulisan ini adalah untuk mengetahui model-model evaluasi pendidikan.

${ }^{3}$ Ramayulis, Ilmu Pendidikan Islam, (Jakarta: Kalam Mulia, 2013), cet. ke 10, h. 397

${ }^{4}$ Purwanto, Evaluasi Hasil Belajar, (Yogyakarta: Pustaka Pelajar, 2009), h. 1

${ }^{5}$ Anas Sudijono, Pengantar Evaluasi Pendidikan, (Jakarta: Raja Grafindo Persada, 2003), h. 5

${ }^{6}$ Oemar Hamalik, Pengembangan Kurikulum, (Bandung: Remaja Rosdakarya, 2007), h. 253

${ }^{7}$ Ramayulis, Op. cit. 


\section{MODEL-MODEL EVALUASI PENDIDIKAN}

Dalam kamus Bahasa Indonesia Model artinya contoh, pola acuan, ragam, macam dan sebagainya. ${ }^{8}$ Secara definisi Model diartikan sebagai a likeness that aid on in understanding a structure process used by scientist, when the phenomena studied would otherwise be underscribable ${ }^{9}$ (sesuatu yang membantu dalam pemahaman struktur atau proses yang digunakan oleh ahli, ketika fenomena dipelajari untuk dapat diterangkan). Sedangkan Evaluasi Pendidikan adalah suatu proses penilaian dalam mengumpulkan dan menganalisis untuk menentukan taraf kemajuan suatu aktivitas di dalam pendidikan guna menetapkan pencapaian suatu tujuan baik untuk pendidik dan peserta didik. ${ }^{10}$

Berdasarkan pengertian di atas dapat penulis simpulkan bahwa Model-model evaluasi pendidikan adalah contoh atau pola acuan suatu proses penilaian dalam mengumpulkan dan menganalisis untuk menentukan taraf kemajuan suatu aktivitas di dalam pendidikan guna menetapkan pencapaian suatu tujuan baik untuk pendidik dan peserta didik.

Evaluasi pendidikan mencakup dua sasaran pokok, yaitu evaluasi makro (Program) dan evaluasi mikro (kelas). Secara umum evaluasi terbagi dalam tiga tahapan sesuai proses belajar mengajar, yaitu dimulai dari evaluasi input, evaluasi proses, dan evaluasi output. Setiap jenis evaluasi memiliki fungsi yang berbeda. Evaluasi input mencakup fungsi kesiapan penempatan dan seleksi.

${ }^{8}$ Desi Anwar, Kamus Bahasa Indonesia Modern, (Surabaya: Amelia, 2002), h. 240

${ }^{9}$ C.V. Good, Dictionary of Education, (New York: Mc. Graw-Hill Book Company, 1973), h. 324

${ }^{10}$ Muhammad Yuda Fauzi, http://yudafauzy.blogspot.co.id/, diakses Tanggal 19 September 2016 
Evaluasi proses mencakup formatif, diagnostik dan monitoring. Sedangkan evaluasi output mencakup sumatif. ${ }^{11}$

Model evaluasi muncul karena adanya usaha eksplanasi ${ }^{12}$ secara kontinu yang diturunkan dari perkembangan pengukuran dan keinginan manusia untuk berusaha menerapkan prinsip-prinsip evaluasi pada cakupan yang lebih abstrak termasuk pada bidang ilmu pendidikan, perilaku, dan seni. ${ }^{13}$

Ada banyak model evaluasi yang dikembangkan oleh para ahli yang dapat dipakai dalam mengevaluasi program pembelajaran. Berikut akan diuraikan beberapa model evaluasi program yang populer dan banyak dipakai sebagai strategi atau pedoman kerja dalam pelaksanaan evaluasi program. yaitu:

\section{Goal Oriented Evaluation Model}

Goal Oriented Evaluation Model ini merupakan model yang muncul paling awal. Yang menjadi objek pengamatan pada model ini adalah tujuan dari program yang yang sudah ditetapkan jauh sebelum program dimulai. Evaluasi dilakukan secara berkesinambungan, terus menerus, mencek

${ }^{11}$ Fungsi kesiapan penempatan adalah untuk mengetahui keterampilan prasyarat yang diperlukan bagi suatu program belajar dan penguasaan belajar seperti yang diprogramkan sebelum memulai kegiatan belajar untuk program tersebut. Fungsi seleksi adalah penilaian yang bertujuan untuk keperluan seleksi seperti ujian saringan masuk perguruan tinggi tertentu dengan berdasarkan kriteria tertentu. Fungsi formatif yaitu penilaian yang dilaksanakan pada akhir program belajar mengajar untuk melihat tingkat keberhasilan proses belajar mengajar. Fungsi diagnostik dan monitoring adalah mengidentifikasi kelemahan-kelemahan siswa dan faktor penyebabnya serta menetapkan cara untuk mengatasi kelemahan atau kesulitan belajar tersebut. Sedangkan Fungsi sumatif adalah penilaian yang dilaksanakan pada akhir unit program, dengan tujuan melihat hasil yang dicapai oleh para siswa, dengan kata lain berfungsi untuk mengetahui seberapa jauh suatu proses pendidikan telah mencapai tujuan yang telah ditentukan. lih. Neneng Lina, Op. cit., h. 234-235

${ }^{12}$ Eksplanasi artinya tindakan menerangkan atau menjelaskan dan keterangan, pernyataan atau fakta yang menjelaskan. lih. Hetty Rusyanti, http: // www.kajianteori.com /2015 /02/pengertian-teks-eksplanasi.html, diakses Tanggal 19 September 2016

${ }^{13}$ Sukardi, Evaluasi Pendidikan, (Jakarta: Bumi Aksara, 2012), cet. ke 7, h. 55 
seberapa jauh tujuan tersebut sudah terlaksana di dalam proses pelaksanaan program. Model ini dikembangkan oleh Tyler. ${ }^{14}$

Di samping itu, Sukardi juga mengatakan bahwa model ini secara konsep menekankan adanya proses evaluasi secara langsung didasarkan atas tujuan instruksional yang telah ditetapkan bersamaan dengan persiapan mengajar, ketika seorang guru berinteraksi dengan para siswanya menjadi sasaran pokok dalam proses pembelajaran. proses pembelajaran dikatakan berhasil menurut para pendukung model yang dikembngkan tyler ini, apabila para siswa yang mengalami proses pembelajaran dapat mencapai tujuan yang telah ditetapkan dalam proses belajar mengajar. ${ }^{15}$

Tujuan sebagai pedoman untuk dievaluasi secara konsep diajukan oleh Tyler dalam Basic Principles of curriculum and Instruction, Ia menyatakan bahwa proses evaluasi esensinya adalah suatu proses dan kegiatan yang dilakukan oleh seorang evaluator untuk menentukan pada kondisi apa tujuan bisa dicapai.

Usaha memahami tujuan hidup seorang siswa dalam proses belajar tidaklah mudah. Hal ini karena pada prinsipnya akan selalu terjadi perubahan, seiring dengan umur, hasil belajar dan tingkat pengalaman hidup seorang anak manusia. Dalam proses pembelajaran, tujuan perlu direncanakan oleh seorang guru, dengan prinsip bahwa untuk menentukan hasil perubahan yang diinginkan dalam bentuk perilaku siswa, seorang guru perlu melakukan evaluasi. Dengan evaluasi ini diharapkan seorang guru dapat menentukan derajat atau tingkat perubahan perilaku siswa yang terjadi, sebagai akibat

${ }^{14}$ Suharsimi Arikunto dan Cepi Safruddin Abdul Jabar, Op. cit., h. 41

${ }^{15}$ Sukardi, Op. cit., h. 56 
perencanaan proses pembelajaran yang dilakukan oleh seorang guru kepada para siswa. ${ }^{16}$

Jika dibandingkan dengan beberapa macam model pendekatan lain, pendekatan Tyler ini memiliki model yang berbeda. Pendekatan Tyler ini pada prinsipnya menekankan perlunya suatu tujuan dalam proses belajar mengajar. Pendekatan ini merupakan pendekatan sistematis, elegan, akurat, dan secara internal memiliki rasional yang logis. Dibandingkan dengan model evaluasi lainnya kesederhanaan model Tyler juga merupakan kelebihan tersendiri dan merupakan kekuatan konstruk yang elegan serta mencakup evaluasi kontingensi. ${ }^{17}$

Dalam implementasinya, model Tyler ini juga menggunakan unsur pengukuran dengan usaha secara konstan, paralel, dengan inquiry ilmiah dan melengkapi legitimasi untuk mengangkat pemahaman tentang evaluasi. Pada model Tyler ini sangat membedakan antara konsep pengukuran dan evaluasi. Menurut Tyler, pengetahuan pengukuran dan pengetahuan evaluasi terpisah dan merupakan proses di mana pengukuran hanya salah satu dari beberapa cara dalam mendukung tercapainya evaluasi. Fokus model Tyler pada prinsipnya adalah lebih menekankan perhatian pada sebelum dan sesudah perencanaan kurikulum. Di samping itu, model Tyler juga menekan bahwa perilaku yang diperlukan diukur minimal dua kali, yaitu sebelum dan sesudah perlakuan (treatment) dicapai oleh pengembang kurikulum. ${ }^{18}$

\footnotetext{
${ }^{16}$ Ibid.

${ }^{17}$ Kontingensi adalah suatu keadaan atau situasi yang diperkirakan akan segera terjadi, tetapi mungkin juga tidak akan terjadi. lih. totokhartanto, http://pasagmerapi.blogspot.co.id/2012/10/prinsip-dasar-rencana-kontigensi.html, diakses Tanggal 19 September 2016

${ }^{18}$ Sukardi, Op. cit.
} 
Dari penjelasan-penjelasan di atas dapat penulis simpulkan bahwa Goal Oriented Evaluation Model adalah Model evaluasi yang dikembangkan oleh Tyler yang berorintasi pada tujuan suatu program yang akan dilakukan, dengan dilakukan model evaluasi ini, diharapkan bisa mengetahui sejauh mana tujuan yang telah ditetapkan tersebut sudah terlaksana atau tercapai.

\section{Goal Free Evaluation Model}

Model evaluasi yang dikembangkan oleh Michael Scriven ini dapat dikatakan berlawanan dengan model pertama yang dikembangkan Tyler, evaluator terus-menerus memantau tujuan, yaitu sejak awal proses terus melihat sejauh mana tujuan tersebut sudah tercapai, dalam model goal free evaluation (evaluasi lepas dari tujuan) justru menoleh dari tujuan. Menurut mechael scriven, dalam melaksanakan evaluasi program evaluator tidak perlu memperhatikan apa yang menjadi tujuan program. Yang perlu diperhatikan dalam program tersebut adalah bagaimana kerjanya program, dengan jalan mengidentifikasi penampilan-penampilan yang terjadi baik hal positif (hal yang diharapkan) maupun hal negatif (memang tidak diharapkan).

Alasan mengapa tujuan program tidak perlu diperhatikan karna ada kemungkinan evaluator terlalu rinci mengamati tiap-tiap tujuan khusus. Jika masing-masing tujuan khusus tercapai, artinya terpenuhi dalam penampilan, tetapi evaluator lupa memperhatikan sejauh mana masing-masing penampilan tersebut mendukung penampilan terakhir yang diharapkan oleh tujuan umum maka akibatnya jumlah penampilan khusus ini tidak banyak bermanfaat.

Dari uraian ini dijelaskan bahwa yang dimaksud dengan "evaluasi lepas dari tujuan" dalam model ini bukannya lepas sama sekali dari tujuan tetapi 
hanya lepas dari tujuan khusus. Model ini hanya mempertimbangkan tujuan umum yang akan dicapai oleh program, bukan secara rinci perkomponen. ${ }^{19}$

Dari penjelasan di atas dapat penulis simpulkan bahwa Goal Free Evaluation Model (model evaluasi lepas dari tujuan). Model evaluasi ini dikembang oleh Michael Scriven. Model ini berlawanan dengan pertama di atas yang orientasinya pada Tujuan, Sementara Model yang kedua ini adalah model evaluasi yang lepas dari tujuan. Namun, penekanannya di sini bahwa lepas dari tujuan maksudnya adalah lepas dari tujuan khusus, bukan dari tujuan umum. model ini masih tetap mempertimbangkan tujuan umum dari sebuah program.

\section{Formatif Sumatif Evaluation Model}

Selain model "evaluasi lepas dari tujuan". Michael Scriven juga mengembangkan model lain, yaitu model formatif-sumatif. Model ini menunjukan adanya tahapan dan lingkup objek yang dievaluasi, yaitu evaluasi yang dilakukan pada waktu program masih berjalan (disebut evaluasi formatif) dan ketika program sudah selesai atau berakhir (disebut evaluasi sumatif).

Berbeda dengan model yang pertama dikembangkan, model yang kedua ini ketika melaksanakan evaluasi, evaluator tidak dapat dapat melepaskan diri dari tujuan. Tujuan evaluasi formatif memang berbeda dengan tujuan evaluasi sumatif. Dengan demikian, model yang dikemukakan oleh Michael Scriven ini menunjuk tentang “apa, kapan, dan tujuan” evaluasi tersebut dilaksanakan.

Evaluasi formatif secara prinsip merupakan evaluasi yang dilaksanakan ketika program masih berlangsung. Tujuan evaluasi formatif tersebut adalah 
untuk mengetahui seberapa jauh program yang dirancang dapat berlangsung, sekaligus dapat mengidentifikasi hambatan. Dengan diketahuinya hambatan dan hal-hal yang menyebabkan program tidak lancar, pengambil keputusan secara dini dapat mengadakan perbaikan yang mendukung kelancaran pencapaian tujuan program.

Evaluasi sumatif dilakukan setelah program berakhir. Tujuan dari evaluasi sumatif adalah untuk mengukur ketercapaian program. Fungsi evaluasi sumatif dalam evaluasi program pembelajaran dimaksudkan sebagai sarana untuk mengetahui posisi atau kedudukan individu didalam kelompoknya. Mengingat bahwa objek sasaran dan waktu pelaksanaan berbeda antara evaluasi formatif dan sumatif, maka lingkup sasaran yang dievaluasi juga berbeda. ${ }^{20}$

Senada dengan uraian diatas, Ramayulis mengatakan bahwa Evaluasi formatif adalah evaluasi yang digunakan untuk mengetahui hasil belajar yang dicapai peserta didik setelah ia menyelesaikan program dalam satuan bahan pelajaran dalam satu bidang studi tertentu. Sedangkan evaluasi sumatif adalah evaluasi yang dilakukan terhadap hasil belajar peserta didik setelah mengikuti pelajaran dalam satu caturwulan, satu semester, atau akhir tahun untuk menentukan jenjang berikutnya. ${ }^{21}$

Berdasarkan penjelasan-penjelasan di atas dapat penulis simpulkan bahwa Formatif Sumatif Evaluation Model adalah model evaluasi yang dilaksanakan dalam waktu yang berbeda, jika melaksanakan evaluasi ketika kegiatan atau program sedang berlangsung ini disebut evaluasi formatif.

\footnotetext{
${ }^{20}$ Ibid., h. 42

${ }^{21}$ Ramayulis, Op. cit., h. 406-407
} 
Sedangkan melaksanakan evaluasi di akhir kegiatan atau program ini disebut evaluasi sumatif.

\section{Countenance Evaluation Model}

Model ini dikembangkan oleh Stake. Model stake menekankan pada adanya pelaksanaan dua hal pokok, yaitu (1) deskripsi (description) dan (2) pertimbangan (judgments). Model ini juga membedakan adanya tiga tahapan dalam evaluasi program, yaitu (1) anteseden (antecedents/ context), (2) transaksi (transaction/proses), dan (3) keluaran (output-outcomes). Oleh Stake, model evaluasi yang diajukan dalam bentuk diagram, menggambarkan deskripsi dan tahapan seperti brikut:

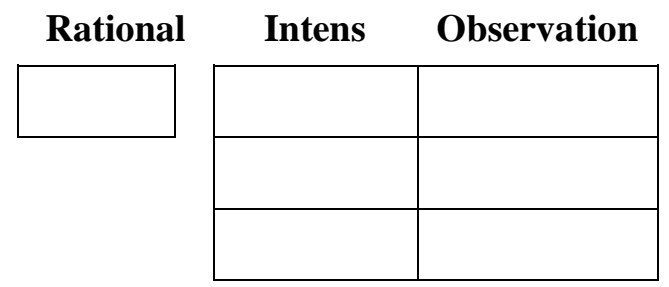

Description Matrix

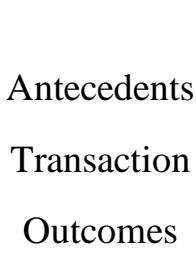

Gambar 1. Evaluasi Model Stake

Tiga hal yang dituliskan di antara dua diagram, menunjukkan objek atau sasaran evaluasi. Dalam setiap program yang dievaluasi, evaluator harus mampu mengidentifikasi tiga hal, yaitu (1) anteseden - yang diartikan sebagai konteks (2) transaksi - yang diartikan sebagai proses, dan (3) Outcomes - yang diartikan sebagai hasil. Selanjutnya, kedua matriks yang digambarkan sebagai deskripsi dan ppertimbangan, menunjukkan langkahlangkah yang terjadi selama proses evaluasi.

Matriks pertama, yaitu deskripsi, berkaitan atau menyangkut dua hal yang menunjukkan posisi sesuatu (yang menjadi sasaran evaluasi), yaitu apa maksud/tujuan yang diharapkan oleh program, dan pengamatan/akibat, atau apa yang sesungguhnya terjadi. Selanjutnya evaluator mengikuti matriks 
kedua, yang menunjukkan langkah pertimbangan, yang dalam langkah tersebut mengacu pada standar.

Menurut Stake, ketika evaluator tengah mempertimbangkan program pendidikan, mereka mau tidak mau harus melakukan dua perbandingan, yaitu:

1. Membandingkan kondisi hasil evaluasi program tertentu dengan yang terjadi di program lain, dengan objek sasaran yang sama;

2. Membandingkan kondisi hasil pelaksanaan program dengan standar yang diperuntukkan bagi program yang bersangkutan, didasarkan pada tujuan yang akan dicapai. ${ }^{22}$

Berdasarkan penjelasan-penjelasan di atas dapat penulis simpulkan bahwa Countenance Evaluation Model adalah model evaluasi yang dikembagkan oleh Stake. Model ini menekan pada dua hal pokok, yaitu deskripsi dan pertimbangan. yang didalamnya ada tiga hal pokok yang menjadi objek atau sasaran evaluasi, dan bagi evaluator harus mampu mengidentifikasi tiga hal itu, yaitu (1) anteseden - yang diartikan sebagai konteks (2) transaksi - yang diartikan sebagai proses, dan (3) Outcomes yang diartikan sebagai hasil.

\section{PENUTUP}

Dari uraian yang telah dikemukakan pada pembahasan di atas dapat ditarik kesimpulan sebagai berikut:

1. Model-model evaluasi pendidikan adalah contoh atau pola acuan suatu proses penilaian dalam mengumpulkan dan menganalisis untuk menentukan taraf

${ }^{22}$ Suharsimi Arikunto dan Cepi Safruddin Abdul Jabar, Op. cit., h. 43-44 
kemajuan suatu aktivitas di dalam pendidikan guna menetapkan pencapaian suatu tujuan baik untuk pendidik dan peserta didik.

2. Goal Oriented Evaluation Model adalah Model evaluasi yang dikembangkan oleh Tyler yang berorintasi pada tujuan suatu program yang akan dilakukan, dengan dilakukan model evaluasi ini, diharapkan bisa mengetahui sejauh mana tujuan yang telah ditetapkan tersebut sudah terlaksana atau tercapai.

3. Goal Free Evaluation Model (model evaluasi lepas dari tujuan). Model evaluasi ini dikembang oleh Michael Scriven. Model ini berlawanan dengan pertama di atas yang orientasinya pada Tujuan, Sementara Model yang kedua ini adalah model evaluasi yang lepas dari tujuan. Namun, penekanannya di sini bahwa lepas dari tujuan maksudnya adalah lepas dari tujuan khusus, bukan dari tujuan umum. model ini masih tetap mempertimbangkan tujuan umum dari sebuah program.

4. Formatif Sumatif Evaluation Model adalah model evaluasi yang dilaksanakan dalam waktu yang berbeda, jika melaksanakan evaluasi ketika kegiatan atau program sedang berlangsung ini disebut evaluasi formatif. Sedangkan melaksanakan evaluasi di akhir kegiatan atau program ini disebut evaluasi sumatif. Model evaluasi ini juga dikembang oleh Michael Scriven.

5. Countenance Evaluation Model adalah model evaluasi yang dikembagkan oleh Stake. Model ini menekan pada dua hal pokok, yaitu deskripsi dan pertimbangan. yang didalamnya ada tiga hal pokok yang menjadi objek atau sasaran evaluasi, dan bagi evaluator harus mampu mengidentifikasi tiga hal itu, yaitu (1) anteseden - yang diartikan sebagai konteks (2) transaksi - yang diartikan sebagai proses, dan (3) Outcomes - yang diartikan sebagai hasil. 


\section{DAFTAR PUSTAKA}

Anwar, Desi. Kamus Bahasa Indonesia Modern. Surabaya: Amelia. 2002

Arikunto, Suharsimi, Dasar-dasar Evaluasi Pendidikan, Jakarta: Bumi Aksara, 2007, ed. Revisi, cet. 7

C.V. Good, Dictionary of Education, New York: Mc. Graw-Hill Book Company, 1973

Suharsimi dan Cepi Safruddin Abdul Jabar, Evaluasi Program Pendidikan: Pedoman Teoretis Praktis Bagi Praktis Pendidikan, Jakarta: Bumi aksara, 2010

Hamalik, Oemar, Pengembangan Kurikulum, Bandung: Remaja Rosdakarya, 2007

Lina, Neneng, Perencanaan Pendidikan, Bandung: Pustaka Setia, 2001

Purwanto, Evaluasi Hasil Belajar, Yogyakarta: Pustaka Pelajar, 2009

Ramayulis, Ilmu Pendidikan Islam, (Jakarta: Kalam Mulia, 2013), cet. ke 10

Sudijono, Anas, Pengantar Evaluasi Pendidikan, Jakarta: Raja Grafindo Persada, 2003

Rusyanti, Hetty http: // www.kajianteori.com /2015 /02/pengertian - teks eksplanasi.html, diakses Tanggal 19 September 2016

Sukardi, Evaluasi Pendidikan, (Jakarta: Bumi Aksara, 2012), cet. ke 7

Totokhartanto, $\quad$ http://pasag-merapi.blogspot.co.id/2012/10/prinsip-dasarrencana-kontigensi.html, diakses Tanggal 19 September 2016

Yuda Fauzi, Muhammad, http://yudafauzy.blogspot.co.id/, diakses Tanggal 19 September 2016. 